\title{
Impact of cloud-borne aerosol representation on aerosol direct and indirect effects
}

\author{
S. J. Ghan and R. C. Easter \\ Atmospheric Science and Global Change Division, Pacific Northwest National Laboratory, Richland, Washington, USA
}

Received: 16 March 2006 - Published in Atmos. Chem. Phys. Discuss.: 31 May 2006

Revised: 31 July 2006 - Accepted: 14 September 2006 - Published: 21 September 2006

\begin{abstract}
Aerosol particles attached to cloud droplets are much more likely to be removed from the atmosphere and are much less efficient at scattering sunlight than if unattached. Models used to estimate direct and indirect effects of aerosols employ a variety of representations of such cloud-borne particles. Here we use a global aerosol model with a relatively complete treatment of cloud-borne particles to estimate the sensitivity of simulated aerosol, cloud and radiation fields to various approximations to the representation of cloud-borne particles. We find that neglecting transport of cloud-borne particles introduces little error, but that diagnosing cloudborne particles produces global mean biases of $20 \%$ and local errors of up to $40 \%$ for aerosol, droplet number, and direct and indirect radiative forcing. Aerosol number, aerosol optical depth and droplet number are significantly underestimated in regions and seasons where and when wet removal is primarily by stratiform rather than convective clouds (polar regions during winter), but direct and indirect effects are less biased because of the limited sunlight there and then. A treatment that predicts the total mass concentration of cloudborne particles for each mode yields smaller errors and runs $20 \%$ faster than the complete treatment. The errors are much smaller than current estimates of uncertainty in direct and indirect effects of aerosols, which suggests that the treatment of cloud-borne aerosol is not a significant source of uncertainty in estimates of direct and indirect effects.
\end{abstract}

\section{Introduction}

Aerosol particles (AP) can be either suspended in air or attached to hydrometeors such as cloud droplets, ice crystals, rain drops, and snow flakes. When AP become attached to hydrometeors by serving as the nucleus of cloud particles,

Correspondence to: S. J. Ghan

(steve.ghan@pnl.gov) forming by oxidation on or in cloud particles, or colliding and coalescing with hydrometeors, they are considered to be scavenged by the cloud and precipitation particles. However, they are not immediately removed from the atmosphere, and may not be removed at all if the hydrometeor they are scavenged by evaporates. Depending on local conditions (cloud free, non-precipitating warm or cold clouds, precipitation), the majority of the aerosol particle population may exist either as interstitial AP or as AP attached to some form of cloud or precipitation particle. The attachment state of AP is therefore highly variable.

Some aerosol particle processes involve only interstitial aerosol particles (e.g., particle nucleation, coagulation, gravitational settling, dry deposition); some involve AP attached to a single type of cloud/precipitation particle (e.g., aqueous and heterogeneous chemistry), and some involve transfer of AP from one attachment state to another (e.g., nucleation scavenging, Brownian diffusion scavenging, droplet collection, impaction scavenging, melting, and resuspension). The attachment state of an aerosol particle can be expected to strongly influence wet removal (and hence particle lifetime and mass loading) and scattering of sunlight (which for most AP is much more efficient-in terms of scattering cross section per mass of material - when they are unattached).

Given the variety of attachment states of AP and the dependence of most particle formation, transformation, and removal processes on the attachment state, one might expect that model simulations of the atmospheric particle life cycle and of the direct and indirect impact of anthropogenic particles on the energy balance of the atmosphere would depend upon the treatment of AP attachment state in the model.

This issue has received little investigation in global aerosol models because few global models explicitly treat multiple attachment states of AP. Many cloud-scale models have explicitly treated bulk AP mass (Rutledge et al., 1986; Tremblay and Leighton, 1986; Chaumerliac et al., 1987; Easter and Luecken, 1988; Hales, 1989) or both AP mass and

Published by Copernicus GmbH on behalf of the European Geosciences Union. 
Table 1. Treatment of cloud-borne aerosol in global aerosol models.

\begin{tabular}{|c|c|c|}
\hline Model & References & Treatment of Cloud-Borne AP \\
\hline Canadian Aerosol Module & Gong et al., 2002, 2003 & Diagnosed from parameterized activation \\
\hline Community Atmosphere & Barth et al., 2000; & $100 \%$ of aerosol \\
\hline Model (CAM) & Mahowald et al., 2006a, b & \\
\hline CAM-Oslo & Iversen and Seland, 2002 & Prescribed fraction as f(size mode, soluble/insoluble) \\
\hline ECHAM5-HAM & Stier et al., 2005 & $\begin{array}{l}\text { Prescribed fraction as } \mathrm{f} \text { (size mode, soluble/insoluble, } \\
\text { warm/mixed/cold phase, stratiform/cumulus) }\end{array}$ \\
\hline ECHAM/MADE & Lauer et al., 2005 & Prescribed fraction as $\mathrm{f}$ (size, LWC, aerosol composition, warm/cold phase) \\
\hline GISS Model-E & Koch, 2001; Koch et al., 2006 & Predicted from composition-dependent fraction activated, neglecting transport \\
\hline GISS-TOMAS & Adams and Seinfeld, 2002 & Diagnosed from prescribed supersaturation + aqueous - scavenging \\
\hline GLOMAP & Spracklen et al., 2005 & Prescribed activation size threshold \\
\hline GOCART & $\begin{array}{l}\text { Chin et al., 2000, 2002; } \\
\text { Ginoux et al., } 2001\end{array}$ & Prescribed fraction \\
\hline HADAM4 & Jones et al., 2001 & $\begin{array}{l}\text { Predicted from composition-dependent fraction } \\
\text { activated, including transport }\end{array}$ \\
\hline IMPACT & Liu et al., 2005 & $\begin{array}{l}\text { Prescribed fraction from composition-dependent fraction activated for } \\
\text { accumulation mode, Brownian capture for nuclei mode }\end{array}$ \\
\hline LMDZ-LOA & Reddy et al., 2005 & Prescribed fraction as $\mathrm{f}$ (composition) \\
\hline MIRAGE & Easter et al., 2004 & $\begin{array}{l}\text { Predicted with fraction activated } \mathrm{f} \text { (updraft velocity and number, } \\
\text { size, and composition of all aerosol), including transport }\end{array}$ \\
\hline MOZART & Tie et al., 2001, 2005 & Prescribed fraction as $\mathrm{f}($ composition) \\
\hline SPRINTARS & Takemura et al., 2002 & Prescribed fraction \\
\hline
\end{tabular}

number in multiple attachment states (Flossman et al., 1985; Flossman and Pruppacher, 1988; Kreidenweis et al., 1997). Global models are just now beginning to explicitly treat both interstitial AP and AP in cloud drops (cloud-borne). The treatment of cloud-borne AP in most global models is summarized in Table 1. All but a few current global models (Community Climate Model (CAM), CAM-Oslo, ECHAM5, ECHAM/MADE, GLOMAP, GOCART, IMPACT, LMDZLOA, MOZART, SPRINTARS) prescribe the fraction of the particle concentration that is cloud-borne when clouds are present. Different fractions are assumed for different aerosol types (by size and/or composition). One model (GISSTOMAS) diagnoses the cloud-borne fraction from a prescribed supersaturation. Another (Canadian Aerosol Module) diagnoses the cloud-borne fraction from a parameterized activation. A few (HADAM4, MIRAGE, GISS ModelE) separately predict the interstitial and cloud-borne AP concentrations, accounting for the influence of activation, Brownian diffusion, aqueous-phase chemistry, droplet collision/coalescence, droplet collection, convective transport, turbulent transport, and resuspension on the cloud-borne AP concentration. Of these, the HADAM4 and MIRAGE models also transport the cloud-borne as well as the interstitial particles. The treatment of cloud-borne particles in each of these models is defensible, but is likely to give results that differ from results with other treatments.

Since most estimates of direct and indirect effects of anthropogenic aerosol are performed using these global aerosol models, it is not surprising that no study has addressed the dependence of direct and indirect effects on the treatment of the cloud-borne AP. Such is the focus of this investigation.

To provide a common modeling framework spanning the current range of treatments of the AP, we will use the Pacific Northwest National Laboratory (PNNL) Model for Integrated Research of Atmospheric Global Exchanges (MIRAGE) (Easter et al., 2004) with several modifications designed to span the current range of treatments. MIRAGE was designed to refine estimates of direct and indirect effects of aerosols. Easter et al. (2004) describe and evaluate the first generation of MIRAGE, which was based on the NCAR Community Climate Model (CCM2). Here we use the second generation of MIRAGE (Textor et al., 2006; Kinne et al., 2006), which is based on the NCAR Community Atmosphere Model (CAM2) (Kiehl and Gent, 2004). MIRAGE2 shares many of the same treatments of aerosol processes with MIRAGE1, but also has a number of differences. It uses a finite-volume (Lin and Rood, 1996, 1997) rather than a spectral dynamic core. The CAM2 treatments of clouds, turbulence and radiative transfer are used, except that droplet number is predicted (Ghan et al., 1997; Ovtchinnikov and Ghan, 2005) rather than prescribed and the Liu et al. (2005) treatment of autoconversion is used. Cloud ice is not predicted separately from cloud water, but rather is diagnosed as a function of temperature from the predicted cloud condensate (Rasch and Kristjansson, 1998). Optical effects of only the interstitial aerosol are treated, accounting for the influence of water uptake on wet particle size, wet refractive index, and optical properties (Ghan et al., 2001a). Many 
of the primary aerosol and sulfur gas emissions are changed (details in Textor et al., 2006). $\mathrm{OH}$ and $\mathrm{HO}_{2}$ are now offline from Easter et al. (2004), and $\mathrm{H}_{2} \mathrm{O}_{2}$ is treated as in Barth et al. (2000). Aerosol dry deposition is treated following Zhang et al. (2001). In-cloud Brownian diffusion scavenging of interstitial AP is not treated. The same resolution ( $4^{\circ}$ latitude, $5^{\circ}$ longitude, 24 layers) and emissions are used in each treatment of attachment state, so that differences in results can be attributed almost entirely to the treatment of cloud-borne particles. Nudging toward ECMWF analyzed winds and temperature is applied to reduce the influence of natural variability on the signal. Each simulation is run for the period October 1999-December 2002. All results are averaged over the last 3 years of the simulation. Results for different months are very similar to those for the annual mean.

Section 2 describes five different treatments of cloudborne particles implemented in MIRAGE2. Section 3 assesses the computational performance of each treatment. The sensitivity of the aerosol distribution, budget, lifetime, and direct and indirect effects to these treatments is presented in Sect. 4. Conclusions are summarized in Sect. 5.

\section{Treatments of cloud-borne particles}

We consider five different treatments of cloud-borne particles in MIRAGE2. All configurations treat direct effects and first and second indirect effects of aerosols.

\subsection{P-FULL: fully predicted cloud-borne particles}

This is the configuration described by Easter et al. (2004). Cloud-borne number concentration for each of four modes (Aitken, accumulation, coarse dust, coarse sea salt) and cloud-borne mass concentration for each component (sulfate, sea salt, organic carbon, black carbon, soil dust) within each mode are carried as prognostic variables in MIRAGE2. The influence of large-scale transport, activation, aqueous-phase chemistry, droplet collision/coalescence, droplet collection, convective transport, turbulent transport, and resuspension on the cloud-borne particle concentration is treated for each cloud-borne variable. Activation, subgrid transport, aqueous chemistry, resuspension and collection are treated separately for stratiform and convective clouds. For stratiform clouds, activation is treated somewhat differently at cloud base (where it is applied to the flux of AP into the cloud) and in the growing cloud fraction (where it is applied to AP residing in the new cloud fraction), and vertical mixing by turbulence transports activated particles through the cloud and into clear air, where all cloud-borne particles are resuspended (Easter et al., 2004; Ovtchinnikov and Ghan, 2005). Stratiform clouds have memory from time step to time step, so the cloud-borne AP does too. For convective clouds, particles are activated as air is entrained into the cloud, aqueous chemistry occurs in the convective cloud-borne AP, which are transported vertically and resuspended at the detrainment level. Because it is the most complete treatment, this configuration will be considered the reference treatment. Textor et al. (2005) and Kinne et al. (2005) show that for many metrics of performance the MIRAGE2 aerosol simulation is as realistic as simulations by any other aerosol model.

\subsection{P-NOADV: predicted cloud-borne with no advection}

This is identical to P-FULL except that large-scale transport of the cloud-borne particles is neglected (even though cloud liquid water and cloud ice are transported). Vertical mixing by turbulence is still treated because it is strongly coupled with the activation process. Koch et al. (2006) also neglect transport of cloud-borne particles in GISS Model-E. In MIRAGE2 this reduces the number of transported species from 45 to 28 .

\subsection{P-RESUSP: predicted cloud-borne resuspended}

This is identical to P-NOADV, except that stratiform clouds have no memory from time step to time step. At the beginning of each time step, all stratiform clouds are treated as new clouds, droplets are nucleated and AP are activated and then mixed vertically. At the end of the each time step, the stratiform cloud droplets are evaporated and all cloud-borne species are resuspended (converted to interstitial state). This treatment is similar to that of Adams and Seinfeld (2002), except that maximum supersaturation is diagnosed in MIRAGE rather than prescribed as in Adams and Seinfeld.

\subsection{P-TOTM: Predicted cloud-borne number and total mass}

In this treatment, the cloud-borne number and total (over all components) mass concentration for each mode are predicted, accounting for the influence of all processes (activation, vertical mixing, aqueous chemistry, droplet collision and collection, and resuspension) except advection. It differs from treatment P-NOADV in that the total cloud-borne mass, not the cloud-borne mass of each aerosol component, is predicted, and only the total (interstitial plus cloud-borne) mass of each component is predicted rather than separate predictions of interstitial and cloud-borne concentrations. This reduces memory requirements and to a lesser extent computations compared with treatment P-NOADV. The cloud-borne mass of each aerosol component in each mode is diagnosed from the total mass of the component in the mode and the cloud-borne mass fraction for the mode. The cloud-borne mass fraction is determined from the predicted cloud-borne total mass and the predicted interstitial plus cloud-borne total masses of all components. The cloud-borne mass fraction is assumed to be the same for each component within a mode. The number of transported species is 28 . 
Table 2. Mean and root mean square errors of annual and column means, normalized by the global mean of the reference simulation. Also listed is the spatial correlation with the reference simulation.

\begin{tabular}{lrrrrrrrrrrrr}
\hline & \multicolumn{3}{c}{ P-NOADV } & \multicolumn{3}{c}{ P-RESUSP } & & \multicolumn{3}{c}{ P-TOTM } & \multicolumn{3}{c}{ DIAG } \\
\hline & mean & rms & cor & mean & rms & cor & mean & rms & cor & mean & rms & cor \\
\hline Accumulation mode aerosol number & -0.01 & 0.01 & .9999 & -0.11 & 0.15 & .993 & 0.01 & 0.01 & .9999 & -0.11 & 0.13 & .996 \\
Accumulation mode aerosol mass & -0.02 & 0.01 & .9999 & -0.19 & 0.25 & .992 & 0.04 & 0.06 & .9997 & -0.21 & 0.26 & .993 \\
Cloud-borne accumulation mode & 0.13 & 0.20 & .996 & 0.01 & 0.26 & .974 & -0.13 & 0.28 & .971 & 0.10 & 0.27 & .972 \\
aerosol number & & & & & & & & & & & & \\
Droplet number & -0.02 & 0.03 & .9997 & -0.22 & 0.51 & .977 & 0.14 & 0.34 & .997 & -0.14 & 0.36 & .983 \\
CCN@0.2\% & -0.02 & 0.02 & .9999 & -0.19 & 0.21 & .989 & 0.03 & 0.05 & .999 & -0.16 & 0.19 & .993 \\
SW cloud forcing & 0.000 & 0.00 & .9999 & 0.01 & 0.03 & .998 & 0.01 & 0.02 & .9997 & 0.02 & 0.02 & .9995 \\
Anthro indirect & 0.02 & $1.17^{\mathrm{a}}$ & $.801^{\mathrm{a}}$ & 0.08 & $1.31^{\mathrm{a}}$ & $.760^{\mathrm{a}}$ & 0.07 & $1.23^{\mathrm{a}}$ & $.789^{\mathrm{a}}$ & 0.26 & $1.14^{\mathrm{a}}$ & $.777^{\mathrm{a}}$ \\
Aerosol opt depth & -0.02 & 0.02 & .9999 & -0.19 & 0.25 & .984 & 0.03 & 0.06 & .9988 & -0.21 & 0.26 & .987 \\
Direct forcing & 0.01 & 0.01 & .9999 & -0.05 & 0.06 & .995 & 0.01 & 0.01 & .9998 & -0.06 & 0.07 & .996 \\
Anthro direct & -0.03 & 0.08 & .997 & -0.19 & 0.28 & .984 & 0.06 & 0.14 & .997 & -0.19 & 0.28 & .983 \\
\hline
\end{tabular}

${ }^{a}$ RMS errors are large and correlations are low for these statistics because they are computed from the difference between two simulations (see text).

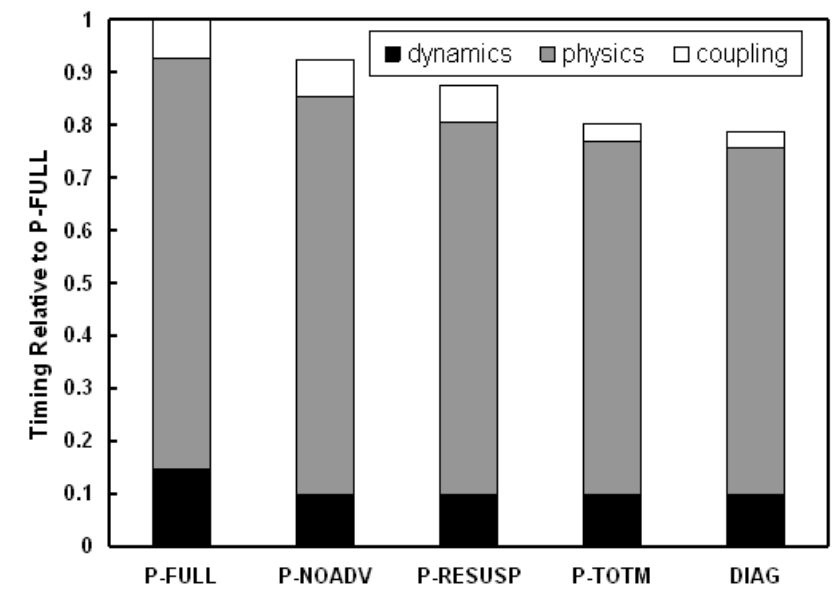

Fig. 1. Decomposition of timing into dynamics, physics, and the coupling between, normalized by the total timing for the P-FULL treatment.

\subsection{DIAG: diagnosed cloud-borne}

To explore the potential for a simpler treatment that retains the same representation of aerosol activation, for DIAG the cloud-borne concentrations of particle number and mass for each mode are diagnosed from the cloud fraction and the fraction activated. The fraction activated is parameterized in terms of the aerosol properties and updraft velocity just as it is in all other versions of MIRAGE (Abdul-Razzak and Ghan, 2000). A separate fraction activated is diagnosed for stratiform and convective clouds. A separate number and mass fraction is diagnosed for each aerosol mode, with the same mass fraction applied to all components within each mode because MIRAGE assumes components within modes are internally mixed. Changes in the cloud-borne fraction due to other processes, such as turbulent transport, aqueousphase chemistry, droplet collision/coalescence, droplet collection, and convective transport are neglected, but these processes are applied to the total (cloud-borne + interstitial) aerosol using the cloud-borne fraction to determine how much of the total aerosol to process. The cloud-borne fraction is used to determine how much of the total (cloudborne + interstitial) aerosol can be scavenged by droplet collision/coalescence (only the cloud-borne aerosol) and by impaction with raindrops (only the interstitial) and how much can scatter and absorb sunlight (only the interstitial). Like in other aerosol models, for DIAG all of the aerosol can coagulate. This configuration is most similar to the treatment in aerosol models using prescribed cloud-borne fraction, and is quite similar to that in the Canadian Aerosol Module; differences between the diagnosed fraction activated and the fraction prescribed in other models are not explored here because such differences depend on the particular value of the fraction prescribed. The number of transported species is 28 .

\section{Computational performance}

The primary reason for not using a fully prognostic treatment of cloud-borne particles is the greater computational burden of the added species. To see this, Fig. 1 shows the profile of run time for 1-day simulations using each of the five treatments. The timings were performed on a linux workstation using dual EM-64 processors. The timing is decomposed into dynamics, physics, and the coupling between. As expected, reducing the number of transported species from 45 to 28 decreases the time spent on dynamics for all alternate treatments. The timing of the physics decreases when other approximations are introduced, resulting in a savings of nearly $20 \%$ in total run time. These results are likely to 
depend somewhat on the computing system; we found increases in run time for the P-NOADV configuration on a 32bit system, presumably caused by less efficient cache utilization when cloud-borne species are stored in a separate block from the interstitial species.

\section{Simulated aerosol distribution and budget}

To focus on the impact of the approximations on the simulated aerosol, our analysis will use scatter plots of the simulated annual mean values at each grid cell for the reference simulation and for each approximate simulation. The 1:1 reference line is shown for each frame. Values printed in the upper left and lower right corners of each frame are the global means for the reference and approximate simulation, respectively. Area-weighted global mean error and root mean square (rms) error, both normalized by the reference global mean value, and the spatial correlation with the reference simulation, are summarized for all fields of interest in Table 2.

The accumulation mode particle number concentration (cloud-borne + interstitial) is perhaps the most important aerosol variable to simulate accurately. Figure 2 shows scatter plots for column-mean accumulation mode particle number concentration for each of the four approximate simulations. The P-NOADV simulation clearly agrees best with the reference simulation (P-FULL), which supports the assumption that liquid cloud lifetimes are sufficiently short that cloud-borne advection can be neglected (Koch et al., 2006). The P-TOTM simulation agrees nearly as well, with the global mean $1 \%$ smaller than the reference, an rms difference less than $2 \%$ of the mean, and a spatial correlation of 0.9999. The simulation that resuspends the cloud-borne particles each time step (P-RESUSP) and the simulation with diagnosed cloud-borne (DIAG) both have a more noticeable (and quite similar) bias, with a global mean only $89 \%$ of the reference mean, an rms difference of $15 \%$ of the mean, and a spatial correlation of $0.993-0.996$.

To understand the bias, the spatial distribution of the ratio of the column number for the P-RESUSP/P-FULL simulations is shown in Fig. 3. The bias is less than $10 \%$ in regions where precipitation is dominated by convection, but increases toward the poles where the column number for the P-RESUSP simulation is only $55-65 \%$ of that for the reference simulation. The latitudinal distribution of column number for each treatment is illustrated in Fig. 4, and the latitude by pressure distribution of the bias in the number concentration with respect to the P-PULL treatment is illustrated for each of the other treatments in Fig. 5. The largest differences in absolute number concentration are in the arctic middle troposphere, where most clouds are stratiform clouds and more aerosols are available to be scavenged. This produces the apparent threshold in the bias evident at column number concentrations of $1.5 \times 10^{12} \mathrm{~m}^{-2}$ for P-RESUSP and
Column Accumulation Mode Number $\left(10^{12} \mathrm{~m}^{-2}\right)$
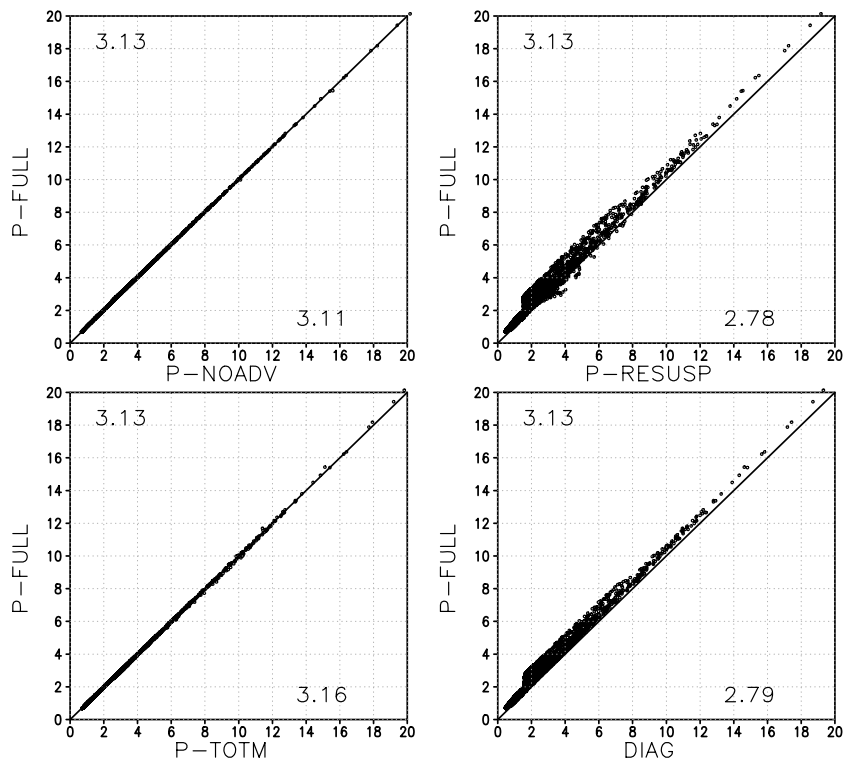

Fig. 2. Scatterplots of annual mean column integrated accumulation mode particle number concentration (cloud-borne + interstitial) for the reference treatment vs. each of the four approximate treatments. The global means for the reference and other treatments are printed in the upper-left and lower-right corners of each plot, respectively.

DIAG in Fig. 2, which is just the local minimum aerosol number burden simulated in the arctic. Since the aerosol simulated in the arctic for the P-FULL case is already too low by a factor of more than two, particularly during the winter months, the reduction in the arctic for the P-RESUSP and DIAG treatments makes the underprediction of arctic aerosol even worse. However, the previous generation of MIRAGE (Easter et al., 2004) did not suffer from this bias, so this conclusion should not be generalized.

Figure 6 and Table 3 show the global budgets and lifetimes, respectively, for accumulation mode AP number. (The budget source terms, which are dominated by primary emissions, are almost identical for the various treatments.) For the DIAG and P-RESUSP treatments, the lifetimes are $\sim 20 \%$ shorter than for the reference and other treatments, and the loss terms (normalized by the global average burdens) are $\sim 20 \%$ larger. The stratiform-cloud wet-removal, "adjustment," and coagulation processes account for most of these differences. Activation followed by precipitation scavenging removes the larger particles in the accumulation mode. When the accumulation mode median size falls below a lower bound, the adjustment term transfers some of the smaller accumulation mode particles to the Aitken mode. The stratiform-cloud wet-removal and adjustment are both significantly greater in the DIAG and P-RESUSP simulations because the activated aerosol is replenished each time step rather than being balanced by activation and scavenging, 
Table 3. Lifetime of accumulation mode particle number for each treatment of cloud-borne particles.

\begin{tabular}{lccccc}
\hline Treatment & P-FULL & P-NOADV & P-RESUSP & P-TOTM & DIAG \\
\hline Lifetime (days) & 3.49 & 3.46 & 3.06 & 3.59 & 3.07 \\
\hline
\end{tabular}

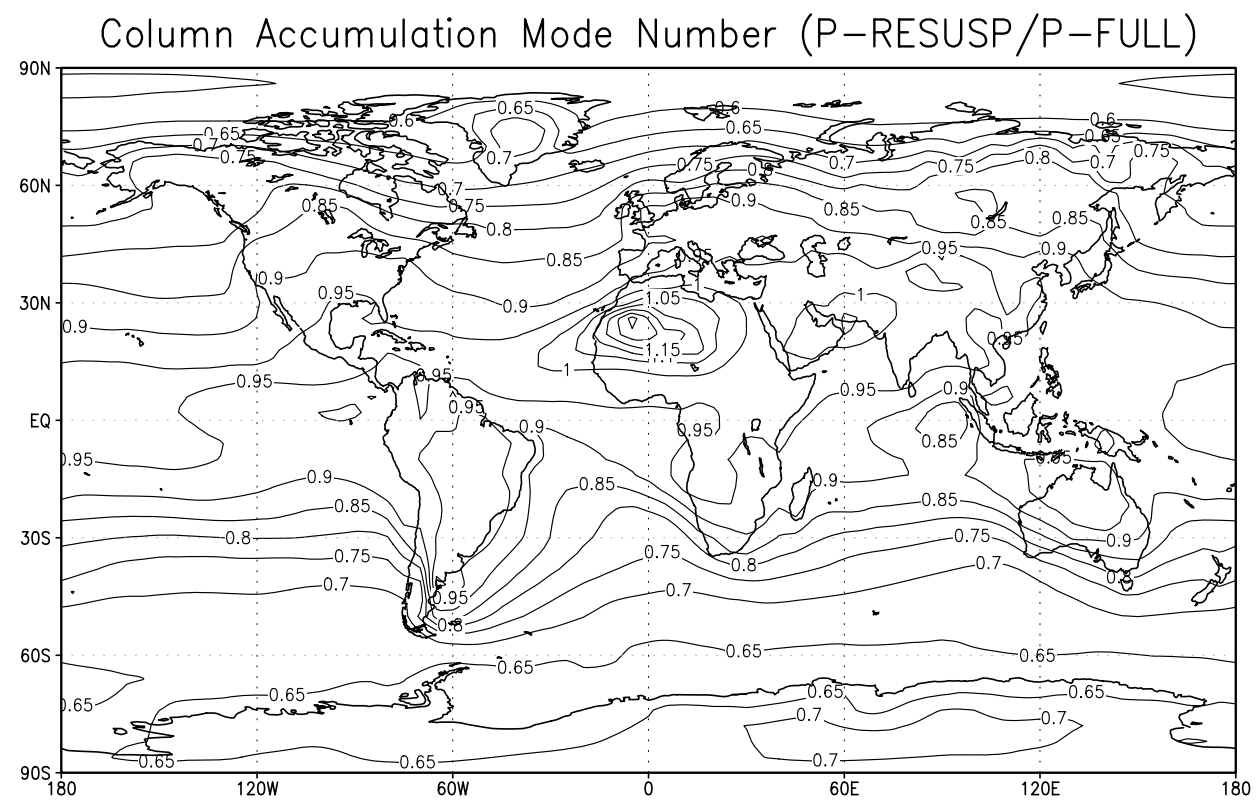

Fig. 3. Ratio of the annual mean column accumulation mode number simulated with the P-RESUSP treatment to that simulated with the reference P-FULL treatment.

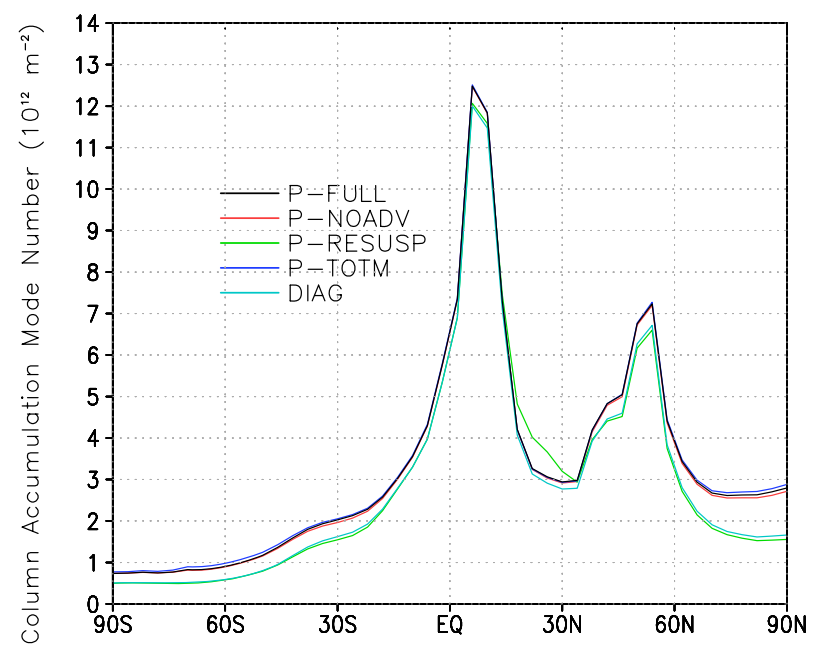

Fig. 4. Longitudinal and annual mean column accumulation mode aerosol number for each treatment of cloud-borne aerosol.

thus biasing the cloud-phase concentrations when in-cloud removal and the adjustment are calculated. Coagulation is also greater because the accumulation mode median size is smaller and because for DIAG it is applied to the total aerosol number. The convective-cloud wet-removal is a larger loss term than the stratiform-cloud wet-removal, but it shows relatively little difference between the various treatments. Similar conclusions hold for accumulation mode mass. Thus the diagnosis of cloud-borne particles in both the P-RESUSP and the DIAG treatments exaggerates nucleation scavenging where stratiform cloud amounts and lifetimes are greatest (such as near the poles), but works where convective clouds are dominate AP wet removal (such as the tropics).

The accumulation mode mass (not shown) exhibits a similar dependence on the treatment of cloud-borne particles. As for accumulation mode number, the P-NOADV and PTOTM treatments produce the best agreement with the $\mathrm{P}$ FULL treatment. Aqueous-phase production of sulfate is nearly the same for all experiments.

The simulated cloud-borne aerosol number concentration should be more sensitive to the treatment of cloud-borne particles. Figure 7 compares the grid cell values of the column accumulation model cloud-borne number concentration for each treatment with the reference treatment. Note that these are for stratiform clouds only, because convective clouds are treated as transitory in all treatments. (Computationally, they 


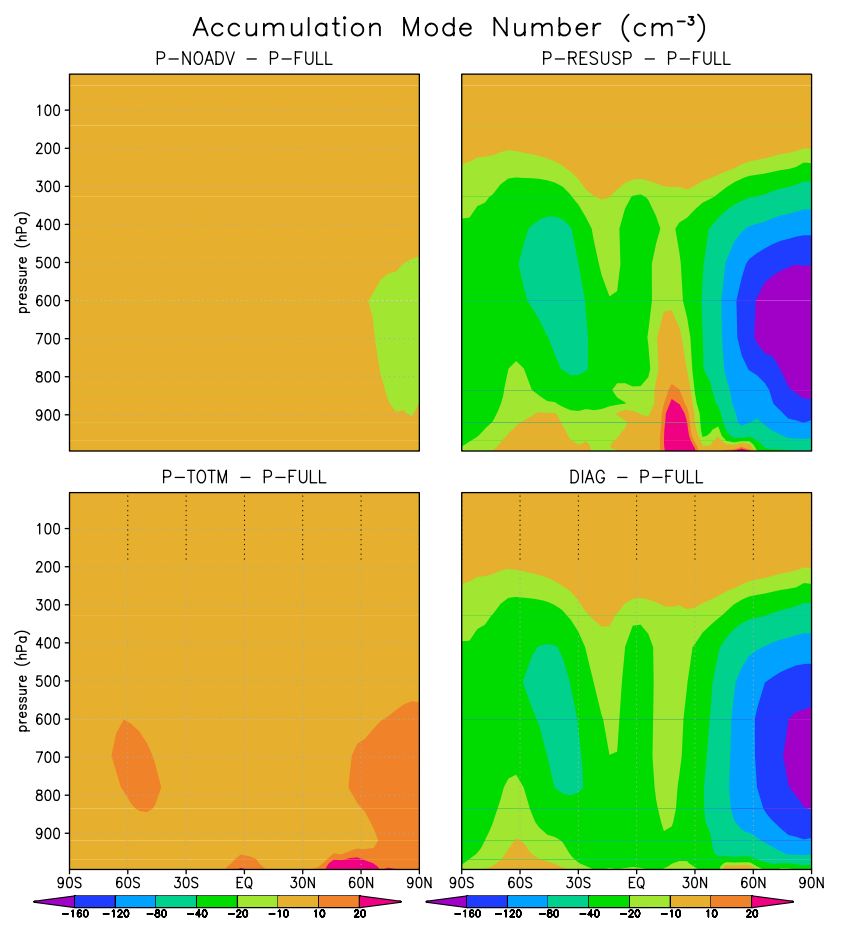

Fig. 5. Longitudinal and annual mean bias in accumulation mode aerosol number for each treatment of cloud-borne aerosol.

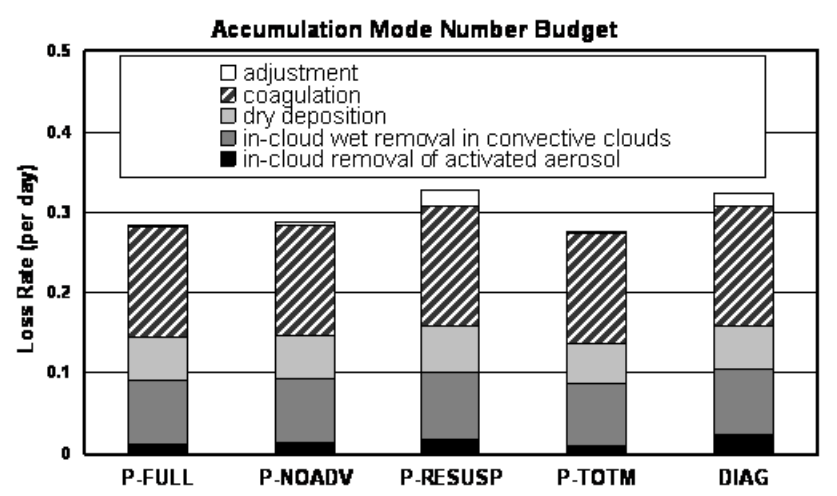

Fig. 6. Global loss budget for accumulation mode number for each treatment of cloud-borne particles. Below-cloud scavenging is negligible and hence is not plotted.

form then dissipate during each time step.) For all treatments, the column-average concentrations for cloud-borne AP are two orders of magnitude less than for the total particles because clouds occupy a small fraction of the atmosphere. As expected, the cloud-borne aerosol simulated with the P-NOADV treatment agrees rather well with the reference treatment. The other treatments yield cloud-borne particle burdens that do not agree with the reference treatment quite so well, but the agreement is better than might be expected considering the differences in the treatments. This has encouraging implications for indirect effects of the aerosol.
Column Accum Mode Cloud-Borne $\mathrm{N}\left(10^{9} \mathrm{~m}^{-2}\right)$
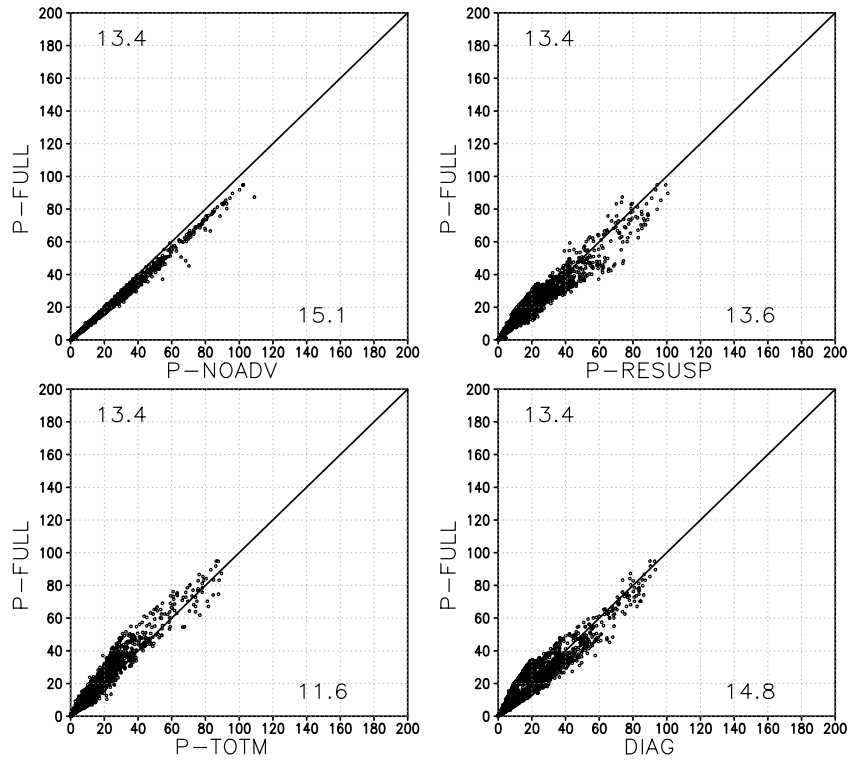

Fig. 7. As in Fig. 2, but for column cloud-borne accumulation mode number.

Column Droplet Number $\left(10^{9} \mathrm{~m}^{-2}\right)$
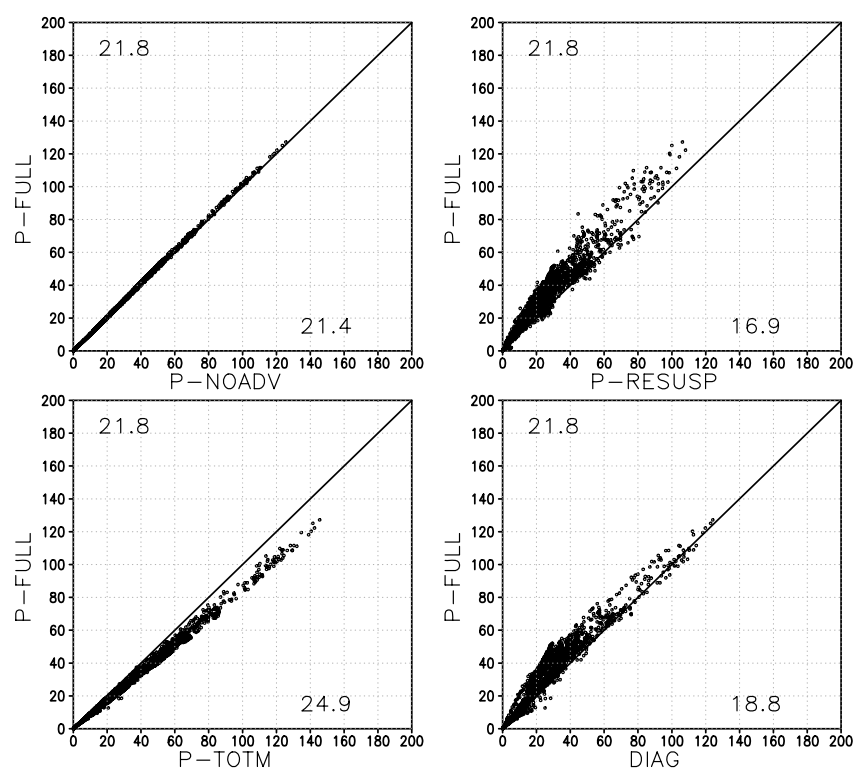

Fig. 8. As in Fig. 2, but for column stratiform-cloud droplet number.

The cloud-borne particle number concentration should, in principle, equal the droplet number concentration. Figure 8 shows scatter plots of column stratiform-cloud droplet number concentration. The global mean droplet number concentration is comparable to the global mean cloud-borne aerosol concentration for all of the treatments of cloud-borne aerosol, 


\section{Shortwave Cloud Radiative Forcing $\left(\mathrm{W} \mathrm{m}^{-2}\right)$}
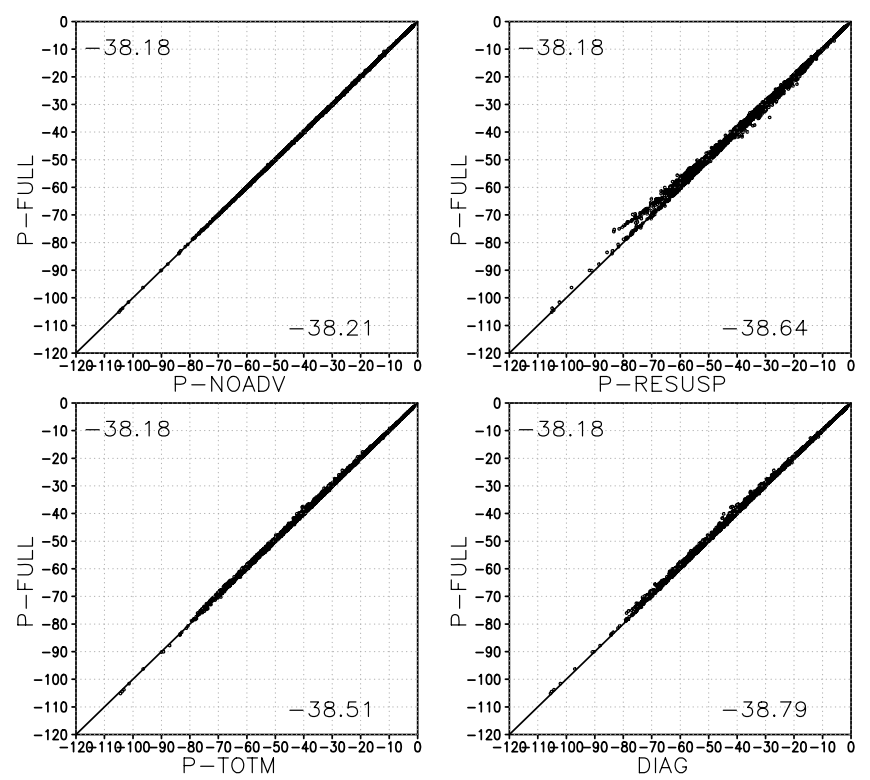

Fig. 9. As in Fig. 2, but for shortwave cloud radiative forcing.

but is larger for all treatments because the cloud-borne particle number from the other three aerosol modes is not included in Fig. 7. Agreement is better when all modes are included, but the cloud-borne aerosol number concentration is still less than the droplet number concentration, particularly in the tropics where deep convection is a net sink of cloudborne aerosol but its effect on droplet number is neglected.

Comparing column droplet number concentrations for the five simulations, the P-NOADV treatment agrees best with the reference treatment. The P-TOTM treatment has a high bias. Column droplet number concentrations simulated with P-RESUSP and DIAG are both biased in a very similar way. These biases can be explained by biases in the column accumulation mode aerosol number. For all fields the largest biases with the P-RESUSP and DIAG treatments are in the polar regions.

These biases have little impact on the shortwave cloud radiative forcing (Fig. 9) because the largest biases are near the poles, where insolation is low. Global means differ by less than $0.5 \mathrm{~W} \mathrm{~m}^{-2}$, and $\mathrm{rms}$ differences are less than $0.7 \mathrm{~W} \mathrm{~m}^{-2}$. Even during polar summer, biases exceed $5 \mathrm{~W} \mathrm{~m}^{-2}$ only in isolated regions. The impact on longwave cloud radiative forcing (not shown) is also negligible. Thus, all radiatively important aspects of clouds are insensitive to the treatment of the aerosols (this conclusion might change if effects of aerosol on ice crystals were treated).

However, if we consider more subtle impacts such as the aerosol indirect effect we find some evidence of a systematic bias. Aerosol indirect effects are usually estimated for a particular subset of the aerosol, such as that produced by
Column Anthro Sulfate Droplet Number $\left(10^{9} \mathrm{~m}^{-2}\right)$
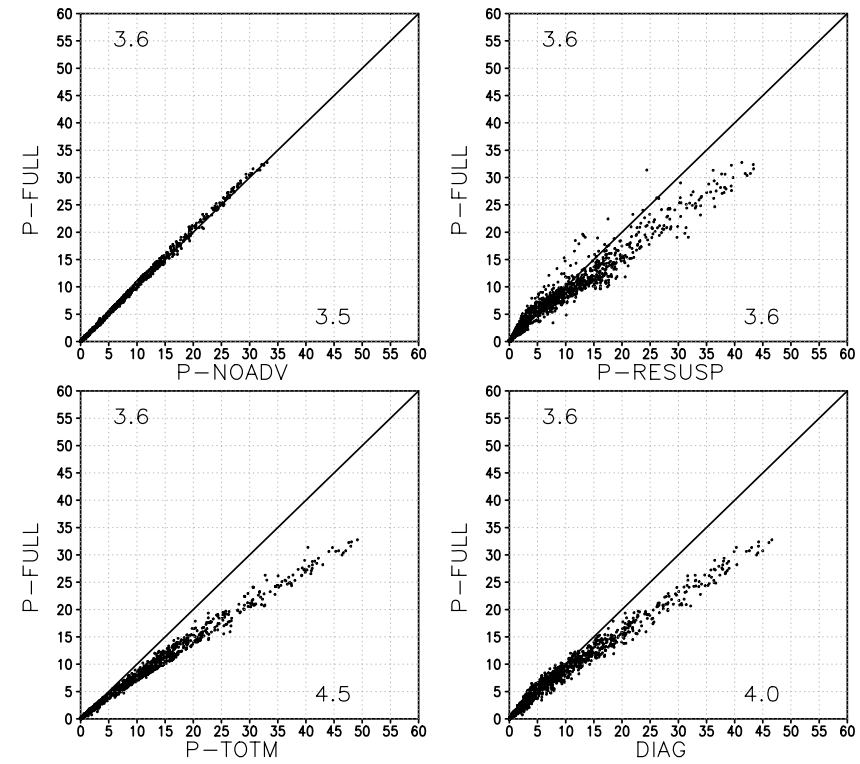

Fig. 10. As in Fig. 2, but for column droplet number increase due to anthropogenic sulfur.

human activity. Here we determine the sensitivity of indirect effects of anthropogenic sulfate aerosol to the treatment of the cloud-borne aerosol. Estimating indirect effects with MIRAGE requires a second set of simulations because, unlike some models, aerosols are full interactive with the meteorology in MIRAGE. A second set of simulations are run, this time without anthropogenic sulfur emissions, and the indirect effect is determined from the difference between the simulations with and without anthropogenic sulfur emissions (Ghan et al., 2001b). Before examining the indirect effect, let us first look at the increase in column droplet number due to anthropogenic sulfur, shown in Fig. 10. We find a systematically larger increase in droplet number for the PTOTM and DIAG treatments. We cannot explain these biases from biases in aerosol number or CCN concentration, which are much smaller. The droplet number biases produce biases in the aerosol indirect effect of anthropogenic sulfur (Fig. 11) for the same treatments, but the biases are relatively small except for the DIAG treatment, which produces a $25 \%$ larger (in magnitude) estimate of the indirect effect than the P-FULL treatment. Much more scatter is evident because the indirect effect is estimated from the difference between two simulations, which contains natural variability due to variations in cloud liquid water path. The indirect effect is notably small for this model, with a global mean value weaker than $-0.25 \mathrm{~W} \mathrm{~m}^{-2}$ for all treatments; explanations for such a small estimate for a similar model are explored by Storelvmo et al. (2006). The global mean indirect effect agrees to within $25 \%$ for all treatments, which suggests that the treatment of 
Anthro Sulfate Indirect Radiative Effect $\left(W \mathrm{~m}^{-2}\right.$ )
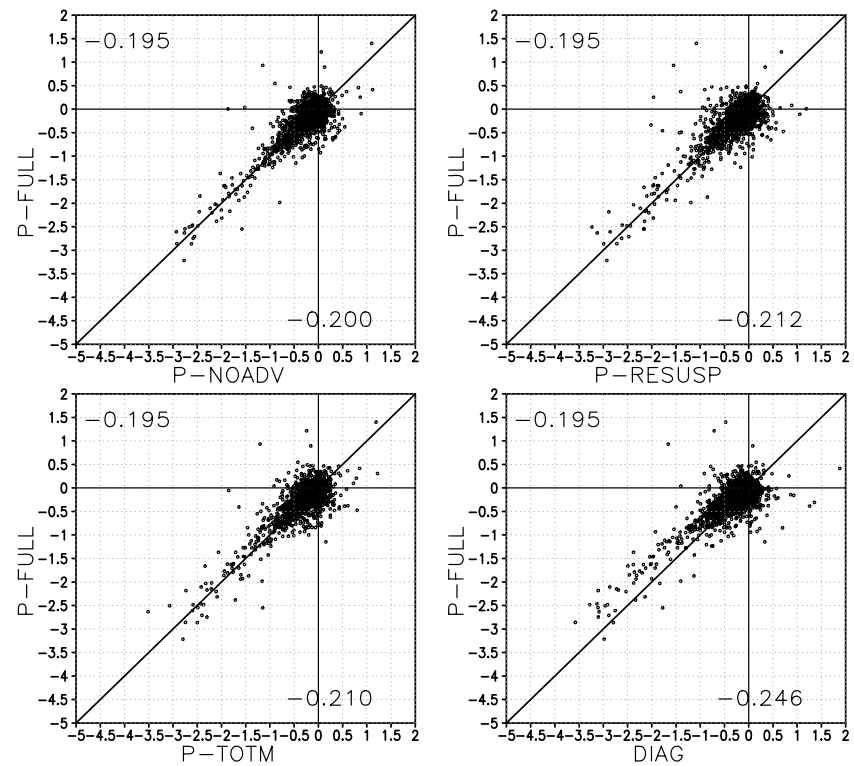

Fig. 11. As in Fig. 2, but for indirect effect due to anthropogenic sulfur.

the cloud-borne aerosol is not a large source of uncertainty in estimates of aerosol indirect effects. However, biases in the treatment of activation and other processes can produce biases in the cloud-borne aerosol and direct and indirect effects of the aerosol; such biases are not explored here.

The message is the same for aerosol direct effects. Figure 12 shows scatter plots for aerosol optical depth for the accumulation mode. The aerosol optical depth simulated by the P-NOADV treatment is in excellent agreement with the P-FULL simulation. The P-TOTM treatment agrees nearly as well. The errors for the P-RESUSP and DIAG treatment are again much larger and are quite similar to each other, with spatial distributions consistent with the errors for column accumulation mode number.

The impact of the bias in aerosol optical depth on the direct radiative forcing of the total (anthropogenic + natural, all modes) aerosol is rather small. Figure 13 shows scatter plots for direct radiative forcing. All treatments yield very similar distributions. The negative sign of the bias is consistent with the positive sign of the bias for optical depth, but the correlations are much higher because the largest biases in optical depth are at polar latitudes where insolation is so low that the impact of the optical depth bias on the direct forcing is very small.

The impact of the aerosol bias on direct forcing by anthropogenic sulfate aerosol is more obvious because the range of values is smaller. Figure 14 shows scatter plots of the direct radiative forcing by anthropogenic sulfate. The forcing from the P-TOTM treatment is too large by $6 \%$, while the forc-
Accumulation Mode Aerosol Optical Depth
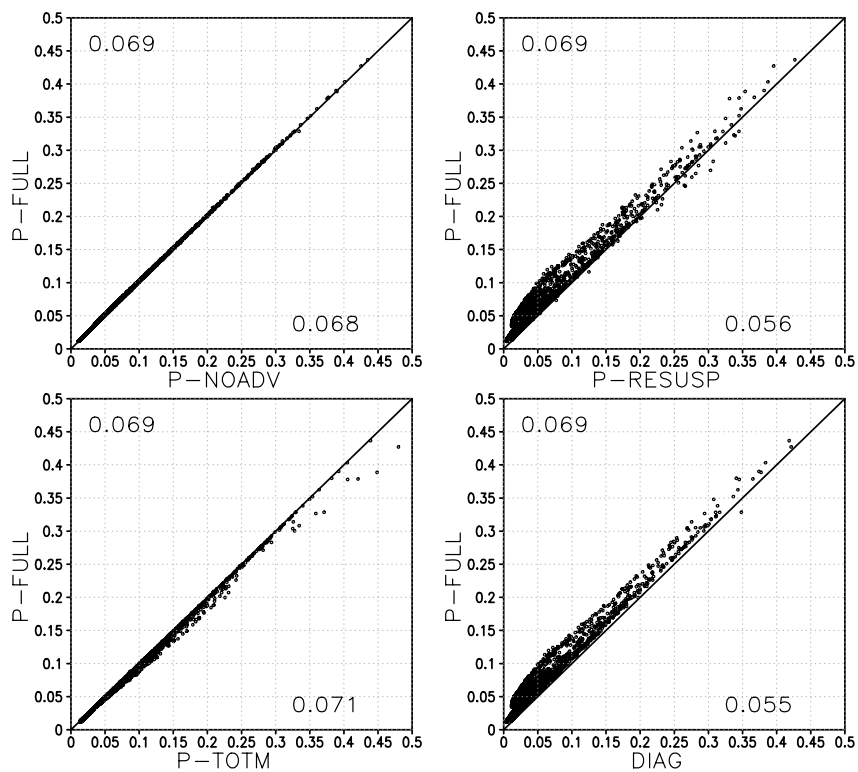

Fig. 12. As in Fig. 2, but for accumulation mode aerosol optical depth.

ing from the P-RESUSP and DIAG treatments are $19 \%$ too small. The underestimate of direct effects of anthropogenic sulfate by the P-RESUSP and DIAG treatments is consistent with underestimates in the anthropogenic aerosol optical depth, but is inconsistent with the overestimate of the anthropogenic increase in column accumulation mode aerosol.

\section{Summary and conclusions}

We have compared global aerosol simulations using five different treatments of the cloud-phase of the particles. The treatments are representative of the range of treatments in models recently used to estimate direct and indirect effects of anthropogenic aerosol, but are certainly not all inclusive. All treatments agree to within $20 \%$ for global means of all aerosol, cloud, and radiation fields examined. Neglecting transport of cloud-borne particles introduces little bias in the simulation, and runs about $10 \%$ faster than simulations that treat transport. Two approximations that diagnose the cloudborne particle concentration in quite different ways both run $20 \%$ faster than the full treatment, but produce the largest errors, with global mean errors of $20 \%$ for many fields and local column burden errors of up to $40 \%$ in regions where AP wet removal is primarily by stratiform rather than convective clouds. Smaller errors result from a treatment that predicts the total mass concentration of cloud-borne particles for each mode; this treatment also runs $20 \%$ faster than the full treatment. Global mean relative errors are largest for the aerosol and droplet number, with largest local errors near 

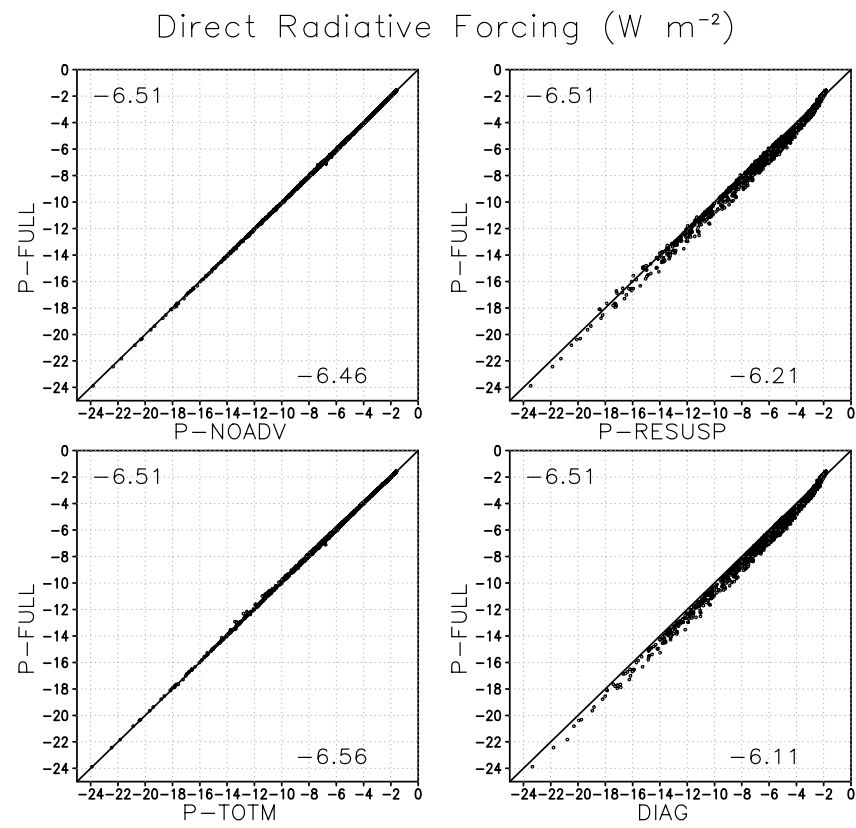

Fig. 13. As in Fig. 2, but for direct forcing by total aerosol.

the poles. Global mean relative errors are smallest for shortwave cloud forcing and direct forcing, which are insensitive to aerosol errors near the poles because insolation is weak there. Global mean relative errors for radiative effects of anthropogenic sulfate are intermediate, because most anthropogenic sulfate is in midlatitudes. None of the errors are as large, even in a relative sense, as current estimates of uncertainty in direct and indirect effects of anthropogenic aerosol (IPCC, 2001). This suggests that the treatment of the cloudborne aerosol is not a large source of uncertainty in direct and indirect effects. Differences between estimates of direct and indirect effects by different models are more likely due to differences in parameterizations of deep convection, cloud microphysics, turbulence, and new particle formation.

We have been unable to explain all of the biases produced by the approximations, particularly those (such as direct and indirect effects on anthropogenic aerosol) that involve many processes and are subtle signals resulting from differences of differences. Inconsistencies between biases in aerosol effects and the aerosol may involve temporal correlations with other fields, like relative humidity or updraft velocity, that also influence the relationship between aerosol and its radiative impact. Such explanations are speculative without high frequency history and additional analysis, which is not worth the effort given the small magnitude of the biases.

These conclusions are likely to be somewhat dependent on resolution. Resolved transport of cloud-borne aerosol is negligible at the coarse resolution considered here, but would undoubtedly be more important at much finer resolutions. Simulations at $2^{\circ} \times 2.5^{\circ}$ resolution suggest such transport can be
Anthro Sulfate Direct Radiative Forcing $\left(\mathrm{W} \mathrm{m}^{-2}\right)$
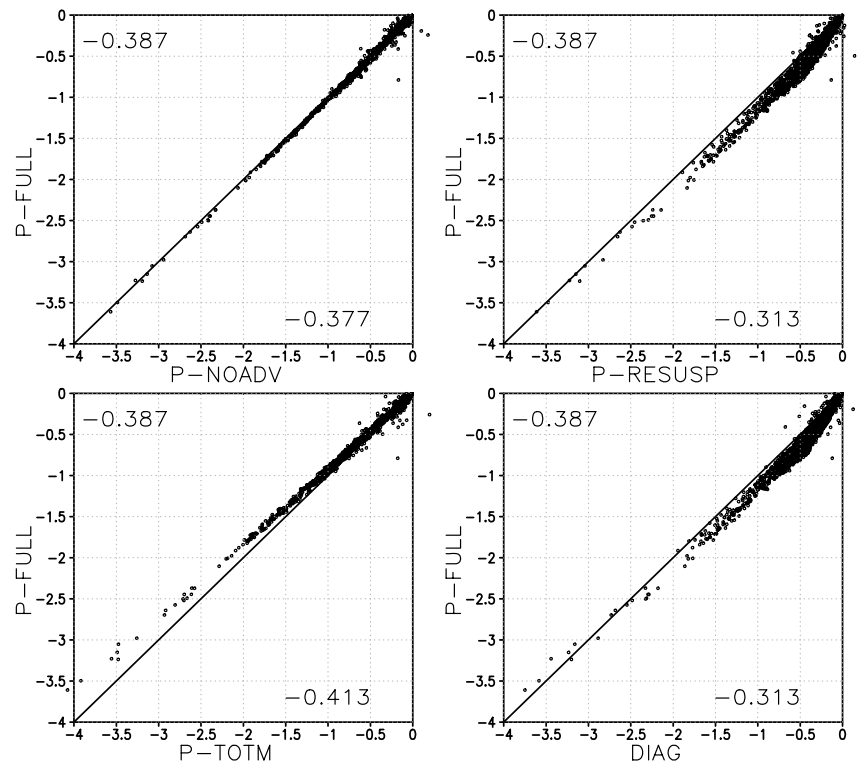

Fig. 14. As in Fig. 2, but for direct forcing due to anthropogenic sulfur.

neglected. Simulations at finer resolution would be required to determine which resolutions are influenced by resolved transport of cloud-borne aerosol.

Do these conclusions apply to other aerosol models? The treatment in many models is similar to the P-RESUSP and DIAG treatments, which yield very similar results that are somewhat biased from the P-FULL treatment. If other models prescribe the supersaturation or the fraction activated in a manner that is less realistic than the variable (and presumably more realistic) supersaturation treatment in MIRAGE, biases could be larger. We have found the relative run time for each treatment to depend on the computing system, and suspect that it would also differ for other aerosol models.

The study has considered the sensitivity to the treatment of only particles in cloud droplets. Attachment of particles to ice crystals can be an important scavenging mechanism for particles such as black carbon and dust that are highly insoluble but may be efficient ice nuclei. Investigation of the sensitivity to the treatment of ice nucleation scavenging will require a model that treats the ice nucleation process reliably.

Acknowledgements. The work reported here was funded by the U.S. Department of Energy, Environmental Science Division's Climate Change Prediction Program and Atmospheric Science Program. The Pacific Northwest National Laboratory is operated for DOE by Battelle Memorial Institute under contract DE-AC0676RLO 1830.

Edited by: U. Lohmann 


\section{References}

Abdul-Razzak, H. and Ghan, S. J.: A parameterization of aerosol activation. Part 2: Multiple aerosol types, J. Geophys. Res., 105, 6837-6844, 2000.

Adams, P. J. and Seinfeld, J. H.: Predicting global aerosol size distributions in general circulation models, J. Geophys. Res., 107, 4370, doi:10.1029/2001JD001010, 2002.

Barth, M., Rasch, P. J., Kiehl, J. T., Benkovitz, C. M., and Schwartz, S. E.: Sulfur chemistry in the NCAR CCM: Description, evaluation, features and sensitivity to aqueous chemistry, J. Geophys. Res, 105, 1387-1415, 2000.

Barth, M. C., Stuart, A. L., and Skamarock, W. C.: Numerical simulations of the July 10, 1996, Stratospheric-Tropospheric Experiment: Radiation, Aerosols, and Ozone (STERAO) Deep Convection experiment storm - Redistribution of soluble tracers, J. Geophys. Res., 106, 12 381-12 400, 2001.

Chaumerliac, N., Richard, E., Pinty, J. P., and Nickerson, E. C.: Sulfur scavenging in a mesoscale model with quasi-spectral microphysics: Two-dimensional results for continental and maritime clouds, J. Geophys. Res., 92, 3114-3126, 1987.

Chin, M., Rood, R. B., Lin, S.-J., Muller, J.-F., and Thompson, A. M.: Atmospheric sulfur cycle in the global model GOCART: Model description and global properties, J. Geophys. Res., 105, 24 661-24 687, 2000.

Chin, M., Ginoux, P., Kinne, S., Torres, O., Holben, B. N., Duncan, B. N., Martin, R. V., Logan, J. A., Higurashi, A., and Nakajima, T.: Tropospheric aerosol optical thickness from the GOCART model and comparisons with satellite and sunphotometer measurements, J. Atmos. Sci., 59, 461-483, 2002.

Easter R. C. and Luecken D. J.: A simulation of sulfur wet deposition and its dependence on the inflow of sulfur species to storms, Atmos. Environ., 22, 2715-2739, 1988.

Easter, R. C., Ghan, S. J., Zhang, Y., Saylor, R. D., Chapman, E. G., Laulainen, N. S., Abdul-Razzak, H., Leung, L. R., Bian, X., and Zaveri, R. A.: MIRAGE: Model description and evaluation of aerosols and trace gases, J. Geophys. Res., 109, D20210, doi:10.1029/2004JD004571, 2004.

Flossmann, A. I., Hall, W. D., and Pruppacher, H. R.: A theoretical study of the wet removal of atmospheric pollutants. Part I: The redistribution of aerosol particles captured through nucleation and impaction scavenging by growing cloud drops, J. Atmos. Sci., 42, 583-606, 1985.

Flossmann, A. I. and Pruppacher, H. R.: A theoretical study of the wet removal of atmospheric pollutants. Part III: The uptake, redistribution, and deposition of $\left(\mathrm{NH}_{4}\right)_{2} \mathrm{SO}_{4}$ particles by a convective cloud using a two-dimensional cloud dynamics model, $\mathrm{J}$. Atmos. Sci., 45, 1857-1871, 1988.

Ghan, S. J., Leung, L. R., Easter, R. C., and Abdul-Razzak, H.: Prediction of droplet number in a general circulation model, J. Geophys. Res., 102, 21 777-21 794, 1997.

Ghan, S., Laulainen, N., Easter, R., Wagener, R., Nemesure, S., Chapman, E., Zhang, Y., and Leung, R.,: Evaluation of aerosol direct radiative forcing in MIRAGE, J. Geophys. Res., 106, 5295-5316, 2001a.

Ghan, S. J., Easter, R. C., Chapman, E., Abdul-Razzak, H., Zhang, Y., Leung, R., Laulainen, N., Saylor, R., and Zaveri, R.: A physically-based estimate of radiative forcing by anthropogenic sulfate aerosol, J. Geophys. Res., 106, 5279-5294, 2001 b.

Ginoux, P., Chin, M., Tegen, I., Prospero, J., Holben, B., Dubovik,
O., and Lin, S.-J.: Sources and global distributions of dust aerosols simulated with the GOCART model, J. Geophys. Res., 106, 20 255-20273, 2001.

Gong, S. L., Barrie, L. B., and Lazare, M.: Canadian Aerosol Module: A size-segregated simulation of atmospheric aerosol processes for climate and air quality models, 2, Global seasalt aerosol and its budgets, J. Geophys. Res., 107, 4779, doi:10.1029/2001JD002004, 2002.

Gong, S. L., Barrie, L. A., Blanchet, J.-P., von Salzen, K., Lohmann, U., Lesins, G., Spacek, L., Zhang, L. M., Girard, E., Lin, H., Leaitch, R., Leighton, H., Chylek, P., and Huang, P.: Canadian Aerosol Module: A size-segregated simulation of atmospheric aerosol processes for climate and air quality models: 1. Module developments, J. Geophys. Res., 108, 4007, doi:10.1029/2001JD002002, 2003.

Hales, J. M.: A generalized multidimensional model for precipitation scavenging and atmospheric chemistry, Atmos. Environ., 23, 2017-2031, 1989.

Intergovernmental Panel on Climate Change: Climatic Change 2001: The Scientific Basis, edited by: Houghton, T. J., Ding, Y., Griggs, D. J., and Noguer, M., Cambridge Univ. Press, Cambridge, U.K., 2001.

Iversen, T. and Seland, O.: A scheme for process-tagged SO4 and BC aerosols in NCAR-CCM3 validation and sensitivity to cloud processes, J. Geophys. Res., 107, 4751, doi:10.1029/2001JD000885, 2002.

Jones, A., Roberts, D. L., Woodage, M. J., and Johnson, C. E.: Indirect sulphate aerosol forcing in a climate model with an interactive sulphur cycle, J. Geophys. Res., 106, 20 293-20310, 2001.

Kiehl, J. T. and Gent, P. R.: The Community Climate System Model, Version Two, J. Clim., 17, 3666-3682, 2004.

Kiehl, J. T., Schneider, T. L., Rasch, P. J., Barth, M. C., and Wong, J.: Radiative forcing due to sulfate aerosols from simulations with the National Center for Atmospheric Research Community Climate Model, Version 3., J. Geophys. Res., 105, 1441-1457, 2000.

Kinne, S., Schulz, M., Textor, C., Guibert, S., Balkanski, Y., Bauer, S., Berntsen, T., Berglen, T., Boucher, O., Chin, M., Collins, W., Dentener, F., Diehl, T., Easter, R., Feichter, H., Fillmore, D., Ghan, S., Ginoux, P., Gong, S., Grini , A., Hendricks, J., Herzog, M., Horrowitz, L., Isaksen, I., Iversen, T., Jones, A., Kloster, S., Koch, D., Krool, M., Lauer, A., Lamarque, J.F., Lesins, G., Liu, X., Lohmann, U., Montanaro, V., Myhre, G., Penner, J., Pitari, G., Reddy, S., Roberts, D., Seland, O., Stier, P., Takemura, T., and Tie, X.: An AeroCom initial assessment - optical properties in aerosol component modules of global models, Atmos. Chem. Phys., 6, 1815-1834, 2006,

http://www.atmos-chem-phys.net/6/1815/2006/.

Koch, D.: Transport and direct radiative forcing of carbonaceous and sulfate aerosols in the GISS GCM, J. Geophys. Res., 106, 20311-20332, 2001.

Koch, D., Schmidt, G. A., and Field, C.: Sulfur, sea salt and radionuclide aerosols in GISS ModelE, J. Geophys. Res., 111, D06206, doi:10.1029/2004/JD005550, 2006.

Kreidenweis, S. M., Zhang, Y., and Taylor, G. R.: The effects of clouds and aerosol and chemical species production and distribution. 2. Chemistry model description and sensitivity analysis, J. Geophys. Res., 102, 23 867-23 882, 1997.

Lauer, A., Hendricks, J., Ackermann, I., Schell, B., Hass, H., 
and Metzger, S.: Simulating aerosol microphysics with the ECHAM/MADE GCM-Part I: Model description and comparison with observations, Atmos. Chem. Phys., 5, 3251-3276, 2005, http://www.atmos-chem-phys.net/5/3251/2005/.

Lin, S.-J. and Rood, R. B.: Multidimensional flux form semilagrangian transport schemes, Mon. Wea. Rev., 124, 2046-2070, 1996.

Lin, S.-J. and Rood, R. B.: An explicit flux-form semi-lagrangian shallow water model on the sphere, Q. J. R. Meteorol. Soc., 123, 2531-2533, 1997.

Liu, X., Penner, J. E., and Herzog, M.: Global modeling of aerosol dynamics: Model description, evaluation and interactions between sulfate and non-sulfate aerosols, J. Geophy. Res., 110, D18206, doi:10.1029/2004JD005674, 2005.

Liu, Y., Daum, P. H., and McGraw, R. L.: Size truncation effect, threshold behavior, and a new type of autoconversion parameterization, Geophys. Res. Lett., 32, L11811, doi:10.1029/2005GL022636, 2005.

Mahowald, N. M., Lamarque, J.-F., Tie, X. X., and Wolff, E.: Seasalt aerosol response to climate change: Last Glacial Maximum, preindustrial, and doubled carbon dioxide climates, J. Geophys. Res., 111, D05303, doi:10.1029/2005JD006459, 2006a.

Mahowald, N. M., Muhs, D. R., Levis, S., Rasch, P. J., Yoshioka, M., Zender, C. S., and Luo, C.: Change in atmospheric mineral aerosols in response to climate: Last glacial period, preindustrial, modern, and doubled carbon dioxide climates, J. Geophys. Res., 111, D10202, doi:10.1029/2005JD006653, 2006b.

Ovtchinnikov, M. and Ghan, S. J.: Parallel simulations of aerosol influence on clouds using a cloud-resolving model and a single column model, J. Geophys. Res., 110, D15S10, doi:10.1029/2004JD005088, 2005.

Rasch, P. J. and Kristjansson, J. E.: A comparison of the ccm3 model climate using diagnosed and predicted condensate parameterizations, J. Clim., 11, 1587-1614, 1998.

Reddy, M. S., Boucher, O., Bellouin, N., Schulz, M., Balkanski, Y., Dufresne, J.-L., and Pham, M.: Estimates of global multicomponent aerosol optical depth and direct radiative perturbation in the Laboratoire de Me'te'orologie Dynamique general circulation model, J. Geophys. Res., 110, D10S16, doi:10.1029/2004JD004757, 2005.

Rutledge, S. A., Hegg, D. A., and Hobbs, P. V.: A numericalmodel for sulfur and nitrogen scavenging in narrow cold-frontal rainbands. 1. Model description and discussion of microphysical fields, J. Geophys. Res., 91, 14 385-14 402, 1986.
Spracklen, D. V., Pringle, K. J., Carslaw, K. S., Chipperfield, M. P., and Mann, G. W.: A global off-line model of size-resolved aerosol microphysics: I. Model development and prediction of aerosol properties, Atmos. Chem. Phys., 5, 2227-2252, 2005, http://www.atmos-chem-phys.net/5/2227/2005/.

Stier, P., Feichter, J., Kinne, S., Kloster, S., Vignati, E., Wilson, J., Ganzeveld, L., Tegen, I., Werner, M., Balkanski, Y., Schulz, M., Boucher, O., Minikin, A., and Petzold, A.: The aerosolclimate model ECHAM5-HAM, Atmos. Chem. Phys., 5, 11251156, 2005, http://www.atmos-chem-phys.net/5/1125/2005/.

Storelvmo, T., Kristjansson, J. E., Ghan, S. J., Kirkevåg, A., and Seland, Ø.: Predicting cloud droplet number concentration in CAM-Oslo, J. Geophys. Res., in press, 2006.

Takemura, T., Nakajima, T., Dubovik, O., Holben, B. N., and Kinne, S.: Single scattering albedo and radiative forcing of various aerosol species with a global three-dimensional model, J. Clim., 15, 333-352, 2002.

Textor, C. , Schulz, M., Guibert, S., Kinne, S., Balkanski, Y., Bauer, S., Berntsen, T., Berglen, T., Boucher, O., Chin, M., Dentener, F., Diehl, T., Easter, R., Feichter, H. Fillmore, D., Ghan, S., Ginoux, P., Gong, S., Grini, A., Hendricks, J., Horrowitz, L., Isaksen, I., Iversen, T., Kloster, S., Koch, D., Kirkevåg, A., Kristjansson, J. E., Krol, M., Lauer, A., Lamarque, J.F., Liu, X., Montanaro, V., Myhre, G., Penner, J., Pitari, G., Reddy, S., Seland, Ø., Stier, P., Takemura, T., and Tie, X.: Analysis and quantification of the diversities of aerosol life cycles within AeroCom, Atmos. Chem. Phys., 6, 1777-1813, 2006,

http://www.atmos-chem-phys.net/6/1777/2006/.

Tie, X., Brasseur, G., Emmons, L., Horowitz, L., and Kinnison, D.: Effects of aerosols on tropospheric oxidants: A global model study, J. Geophys. Res., 106, 2931-2964, 2001.

Tie, X., Madronich, S., Walters, S., Edwards, D. P., Ginoux, P, Mahowald, N., Zhang, R. Y., Lou, C., and Brasseur, G.: Assessment of the global impact of aerosols on tropospheric oxidants, J. Geophys. Res., 110, D03204, doi:10.1029/2004JD005359, 2005.

Tremblay, A. and Leighton, H.: A 3-dimensional cloud chemistry model, J. Appl. Met., 25, 652-671, 1986.

Zhang, L., Gong, S.-L., Padro, J., and Barrie, L.: A size-segregated particle dry deposition scheme for an atmospheric aerosol module, Atmos. Environ., 35, 549-560, 2001. 